\title{
A SHARED DESTINY: DUNGANS
AND THE NEW SILK ROAD
Zhu Yujie
}

T N JUNE 2017, forty-five Muslim students - Dungans 东千族 from Kazakhstan and Kyrgyzstan - celebrated their graduation from a four-year course of study at Northwest Normal University in Lanzhou, Gansu province. They were the first Dungans to graduate with financial support from the provincial governments of Gansu and Shaanxi, as part of a program that began in 2013. Following their Chinese-language training and study of business, agricultural technology, and natural resource management, most of them will return to Central Asia to work as liaisons between Chinese and Central Asian companies. 'We would like to become the messengers along the Silk Road,' the students told Chinese media. ${ }^{4}$
Dungans claim to be descendants of Hui 回, a Muslim Chinese ethnic minority, who fled their homes in Shaanxi and Gansu provinces about 140 years ago after aborted uprisings against the Qing government. Two further waves of migration during the late nineteenth century led to more of these Chinese Muslims settling in Kazakhstan, Kyrghyzstan, and Uzbekistan. Cultural evidence linking Dungans to the Hui of north-western China include their distinctive Chinese-style housing, dietary habits, customs, and spoken dialects.

In September 2013, during Xi Jinping's visit to Kazakhstan, he proposed a 'New Silk Road Economic Belt' 新丝 绸之路经济带, part of what is now re- 
ferred to as the Belt and Road Initiative (see Chapter 2 'The Belt and Road Intiative: How to Win Friends and Influence People’, pp.42-59), involving road and rail construction along the ancient trade route connecting China to $\mathrm{Eu}$ rope via Central Asia. The initiative encourages economic policy coordination among the countries along the route and the 'facilitation of an open, inclusive and balanced regional economic cooperation architecture that benefits all'. ${ }^{5}$ This includes infrastructure building and transnational trade between China and Central Asian countries, Russia, and Europe.

Historical, cultural, and political differences and complex interdependencies among Central Asian countries present a challenge to the plan. So, the Silk Road Economic Belt also explicitly advocates 'people-to-people relations' and a cultural narrative of the Silk Road that promotes the political and economic objectives of the Belt and Road Initiative.

It is in this context that the historical connection between the Dungans and Chinese Muslims in Gansu and Shaanxi has attracted the attention of provincial and local governments, which perceive not just the potential economic advantages of deeper ties between China and its Central Asian neighbours, but also the opportunities for tourism and educational and academic exchange. Over the last decade, the provincial government of Shaanxi and the municipal government of Xi'an have regularly sent official delegations to Dungan communities in Central Asia. The Dungans have welcomed this Chinese initiative. Their proficiency in Russian, Chinese, Kazakh, and other regional languages has allowed them to benefit from the reopening of the Sino-Soviet border for private trade and cultural exchange beginning in the late 1980s. Since 2013, there have been more frequent socio-cultural and economic activities promoting mutually beneficial cooperation, particularly in the areas of agricultural technology (including solar-powered greenhouses and mushroom-growing technology), international trade, tourism, and education exchange.

In 2014 and 2015, the Xi'an municipal government organised a weeklong cultural event called the Dungan Reunion 中亚东千人寻亲西安行. This celebrated the Dungans' ancestral ties and contemporary links with the Hui people, making no mention of the Dungan revolts of 1862-1877 (a chaotic uprising that resulted from racial, 


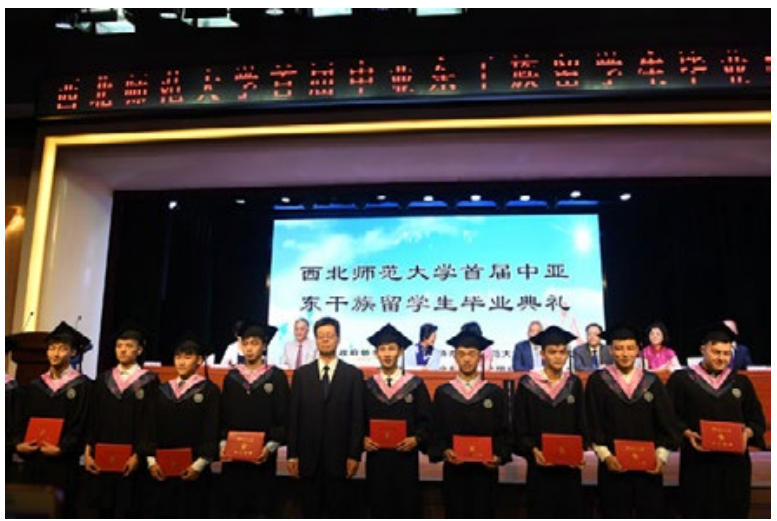

Forty-five Dungans graduated from Northwest Normal University in Lanzhou, Gansu province in June

Image: news.nwnu.edu.cn

religious, and class antagonisms) and the Qing-approved military suppression and massacre of Muslim people led by Zuo Zongtang that drove the Dungans out of China. The Reunion focusses on the positives of cultural, religious, and business connections between Dungans and Hui Muslims. For instance, they made cooperative agreements on cultural tourism programs that bring Central Asian tourists to Xi'an and vice-versa.

The Chinese government clearly hopes that this positive model will be useful in managing politically sensitive and volatile Muslim groups, such as the Uyghurs. It distinguishes itself from a negative approach to managing 'troublesome' ethnic minorities by using connections such as a common ethno-religious identity and mutual interests of cultural and business exchange. When Muslim groups liaise between China and the rest of the world, they are no longer seen as potential threats to challenge the authority of the Chinese Communist Party. Rather, all these activities facilitate the establishment of a new Silk Road community with a 'shared destiny' 共同命运 (see the China Story Yearbook 2014: Shared Destiny). 
This text is taken from China Story Yearbook 2017: Prosperity, edited by Jane Golley and Linda Jaivin, published 2018 by ANU Press, The Australian National University, Canberra, Australia.

doi.org/10.22459/CSY.04.2018.04C 